\title{
HUBUNGAN KADAR GULA DARAH PUASA \\ SAAT TERJADINYA STROKE DENGAN NIH STROKE SCALE \\ PADA PASIEN STROKE ISKEMIK AKUT \\ DI RSUP DR SARDJITO YOGYAKARTA
}

\author{
Hermawan Hanjaya ${ }^{1}$, Paryono ${ }^{2}$, Ismail Setyopranoto ${ }^{2}$, \\ Cempaka Thursina ${ }^{2}$, SekarSatiti ${ }^{2}$
}

${ }^{1}$ RS Bhayangkara, Yogyakarta, Indonesia

${ }^{2}$ Departemen Neurologi, FK-KMK Universitas Gajah Mada/RSUP dr. Sardjito, Yogyakarta, Indonesia

Diterima 06 Oktober 2018

Disetujui 25 Maret 2019

Publikasi 28 Maret 2019

Korespondensi: hermawanhanjaya@gmail.com

\section{ABSTRAK}

Latar belakang: Hiperglikemia terjadi pada 20-50\% pasien stroke iskemik akut, berdampak buruk terhadap luaran klinis.

Tujuan: Mengetahui hubungan antara kadar GDP dengan nilai National Institute Health Stroke Scale (NIHSS) stroke iskemik akut di RSUP Dr Sardjito Yogyakarta.

Metode Penelitian: Penelitian potong lintang pada 50 pasien, Januari-Mei 2018. Kadar GDP pasien diambil saat rawat inap dan skor NIHSS dihitung saat awal dan akhir perawatan.
Cara merujuk artikel ini: Hanjaya (et al). 2019. Hubungan kadar gula darah puasa saat terjadinya stroke dengan NIH stroke scale pada pasien stroke iskemik akut di RSUP dr. Sardjito Yogyakarta. Callosum Neurology Journal 2(1): 34-37. DOI: $10.29342 /$ cnj.v2i1.43

Hasil Penelitian: Analisis Chi-square menunjukkan kemaknaan $(p=0.03)$ antara GDP dengan NIHSS awal (perbedaan proporsi > 30\%). Uji per bedaan GDP dengan NIHSS menunjukkan nilai $p=0,044$.

Simpulan: Terdapat hubungan kadar gula darah puasa dengan skor NIHSS rawat inap, terkait luaran buruk.

Kata Kunci: GDP, NIHSS, stroke iskemik akut, gula darah puasa

\section{ABSTRACT}

Background: Hyperglycemia occurs in 20-50\% in acute ischemic stroke (AIS) patients which worsens ischemic stroke outcome.

Objective: To investigate the association between FBG and National Institute Health Stroke Scale (NIHSS) in AIS patients hospitalized at RSUP Dr Sardjito Yogyakarta.

Methods: This was a cross-sectional study involving 50 participants admitted between January to May 2018. FBG was taken during hospital admission, along with NIHSS, and re-evaluated when at discharge.

Results: Chi-square displayed a significant correlation $(p=0.03)$ between FBG and NIHSS at admission (proportion difference $>30 \%$ ). Mean difference analysis between FBG level with NIHSS admission shows $p$-value $=0.044$.

Conclusion: There is correlation FBG and NIHSS score, indicating worse outcome

Keywords: FBG, NIHSS, acute ischemic stroke, fasting blood glucose 


\section{Latar Belakang}

Stroke adalah salah satu penyebab disabilitias dan mortalitas yang menjadi ancaman di seluruh dunia. Bahkan, menurut data badan kesehatan dunia (WHO), stroke adalah penyakit tertinggi kedua yang menyebabkan kematian, dan menduduki peringkat ketiga sebagai penyakit yang menyebabkan kecacatan. ${ }^{1}$ Data riset kesehatan dasar (Riskesdas) tahun 2007 menunjukkan bahwa stroke merupakan penyebab kematian utama pada semua umur dengan persentase $15,4 \%$. Setiap 7 orang yang meninggal di Indonesia, 1 orang diantaranya karena stroke. $^{2}$

Stroke, merupakan proses kematian dari sel otak yang dikarenakan suplai oksigen yang kurang ke otak. Suplai oksigen tersebut berkurang dikarenakan adanya sumbatan atau pembuluh darah yang pecah. $^{3}$

Sebanyak $75 \%$ dari kejadian stroke iskemik disebabkan oleh stroke trombosis, yaitu sumbatan pada pembuluh darah arteri serebral karena proses aterosklerosis, dan $25 \%$ lainnya merupakan stroke emboli, yaitu terjadi sumbatan arteri serebral oleh bekuan darah yang lepas dari tempat lain di sirkulasi. ${ }^{4}$ Faktor risiko dari penyakit stroke memiliki kesamaan dengan penyakit jantung koroner, dan strategi prevensi dari penyakit tersebut ditargetkan ke arah faktor risiko yang dapat diubah, yaitu hipertensi, dislipidemia dan diabetes. Risiko lain yang dikaitkan dengan faktor gaya hidup juga berpengaruh dengan stroke, seperti rokok, aktivitas fisik yang rendah, dan konsumsi makanan yang tidak sehat. $^{5}$

Kadar gula yang tinggi atau hiperglikemia merupakan kondisi yang sering ditemukan pada pasien stroke, dan dikaitkan dengan angka survival yang lebih rendah. Dan beberapa studi menunjukan adanya kenaikan tingkat mortalitas pada pasien stroke disertai hiperglikemia. ${ }^{6}$ Bahkan ada studi yang mengatakan pasien stroke iskemik akut dengan kadar konsentrasi glukosa yang setara akan memiliki luaran yang setara, dengan atau tanpa adanya riwayat diabetes. $^{7}$

Salah satu skala penilaian yang digunakan untuk mengukur defisit neurologis penderita stroke adalah National Institutes of Health Stroke Scale (NIHSS). Instrumen NIHSS adalah alat ukur kuantitatif yang digunakan untuk mengukur derajat kecacatan stroke dan reliable untuk memprediksi luaran stroke jangka panjang. ${ }^{8}$ Skala luaran NIHSS hingga saat ini masih memiliki beberapa derajat keparahan dimana yang sering digunakan adalah luaran dimana skor $<5$ yaitu ringan, 5-14 yaitu sedang, 5-25 yaitu berat, dan $>25$ yaitu sangat berat. ${ }^{11}$ Sedangkan luaran dengan nilai cut-off 7 diperkirakan sebagai cut-off yang penting untuk memprediksi tingkat keparahan pasien.12,13 Penelitian ini bertujuan untuk mengkaji hubungan antara kadar glukosa darah puasa saat serangan kejadian stroke atau saat admisi, dengan hasil luaran NIHSS.

\section{Metode Penelitian}

Penelitian ini merupakan penelitian observasional dengan menggunakan stroke registry pasien stroke iskemik akut yang dirawat di Rumah Sakit Umum Pusat (RSUP) Dr. Sardjito Yogyakarta yang memenuhi kriteria penelitian. Kriteria inklusi penelitian ini adalah pasien dengan diagnosa stroke iskemik akut dengan pemeriksaan CT scan dan menjalani rawat inap di RSUP dr. Sardjito. Kriteria eksklusi penelitian ini adalah riwayat stroke sebelumnya, gagal hati, gagal ginjal, dan data di stroke registry tidak lengkap. Populasi penelitian ini adalah pasien stroke iskemik akut yang dirawat di RSUP Dr. Sardjito Yogyakarta pada bulan Januari sampai Mei 2018. Seluruh sampel diperiksa laboratorium kadar gula darah puasa saat masuk dan derajat keparahan stroke dinilai menggunakan NIHSS ketika awal masuk dan pemeriksaan NIHSS diulang saat pasien keluar dari rumah sakit. Analisis data menggunakan uji korelasi Pearson, Chi-square, dan T-test dengan menggunakan aplikasi pengolah data. Uji normalitas data menggunakan uji normalitas Shapiro-Wilk.

\section{Hasil Penelitian}

Sejumlah 50 sampel penelitian, terdapat sejumlah 20 pasien dengan kadar gula darah puasa (GDP) $\geq 126$, dan 30 pasien dengan kadar GDP $<126$. Kedua kelompok memiliki persebaran untuk jumlah laki laki dan perempuan yang sama yaitu $60 \%$ untuk laki laki dan $40 \%$ perempuan. Selain itu, ditemukan bahwa riwayat hipertensi pada sampel juga merata, $80 \%$ dari tiap grup memiliki riwayat hipertensi. Hasil pengukuran kadar GDP $\geq 126$ dikaitkan dengan riwayat diabetes yang lebih tinggi. Tercatat 15 orang (75\%) mengalaminya dan hanya 10 orang $(33,3 \%)$ yang memiliki kadar GDP $<126$.

Analisis perbandingan skor total NIHSS berdasarkan kategori kadar GDP (normal dan tidak normal) menggunakan analisis uji Mann- Whitney. Hasil analisis tidak adanya perbedaan skor NIHSS pada kedua kelompok GDP baik pada saat masuk $(p=0,243 ; p>0,05)$ maupun saat keluar rumah sakit $(p=0,173 ; p>0,05)$. Hal serupa didapatkan pada uji Mann-Whitney dengan perbedaan nilai GDP kelompok dengan skor. 
NIHSS saat masuk $\geq 5$ dan $<5 \quad(p=0,505(p>0,05)$. Namun, pada uji perbedaan nilai GDP dengan skor NIHSS saat masuk $\geq 7$ dan $<7$, mengindikasikan bahwa secara rerata, nilai GDP pada kelompok NIHSS masuk $\geq 7$ (Ranking rerata $=32,5 ; n=13$ ) secara signifikan lebih besar dibandingkan dengan kelompok NIHSS masuk $<7$ (Ranking rerata $=23,04$, $n=37), U=149,5 ; z=-2,014, p=0,044)$.

Uji korelasi menggunakan uji spearman antara kadar GDP dan nilai NIHSS masuk menunjukkan hasil analisis yang tidak berbeda bermakna dimana $p=0,344(>0,05)$, disertai dengan kekuatan korelasi sangat lemah yaitu 0,137 . Sedangkan untuk uji korelasi menggunakan Spearman antara kadar gula darah puasa dengan nilai NIHSS keluar juga menunjukkan hasil analisis yang tidak bermakna dimana $p=0,504(>0,05)$, disertai dengan kekuatan korelasi sangat lemah yaitu 0,105.

\section{Pembahasan}

Terdapat hubungan bermakna antara peningkatan kadar glukosa terhadap insiden stroke. Pasien dengan kadar glukosa darah yang tinggi, dapat meningkatkan risiko terkena stroke dua kali lipat dibandingkan pasien dengan kontrol glukosa darah yang baik. Hiperglikemia akan berdampak buruk terhadap luaran klinis penderita karena dapat menyebabkan gangguan fungsi imun, lebih rentan terkena infeksi, perburukan sistem kardiovaskuler, trombosis, peningkatan inflamasi, disfungsi endotel, stres oksidatif, dan kerusakan otak. ${ }^{9}$ Pemeriksaan kadar glukosa darah merupakan pemeriksaan yang perlu dilakukan karena gangguan neurologis dapat sebagai manifestasi klinis dari kondisi hipoglikemia atau hiperglikemia. Hiperglikemia dapat terjadi baik pada penderita stroke yang memiliki riwayat diabetes mellitus maupun yang tidak. Kadar glukosa darah yang tinggi mempengaruhi tingkat keparahan luaran pasien stroke iskemik melalui beberapa cara. Pertama, hiperglikemia akan menyebabkan perubahan sawar darah otak, edema serebri, dan kelainan perdarahan.

Tabel 1. Data demografis pasien didasarkan pada kadar gula darah puasa(GDP)

\begin{tabular}{lcccc}
\hline \multicolumn{1}{c}{ Variabel } & $\mathrm{N}(\%)$ & RDP $<126$ & $\mathrm{~N}(\%)$ & RDS $\geq 126$ \\
\hline Umur & & $63,65(10,63)$ & & $62,35(8,52)$ \\
Jenis Kelamin & & & \\
$\quad$ Laki-Laki & $18(60)$ & & $12(60)$ & \\
$\quad$ Perempuan & $12(40)$ & $8(40)$ & \\
Riwayat HT & & & $16(80)$ & \\
$\quad$ Ya & $24(80)$ & $4(20)$ & \\
$\quad$ Tidak & $6(20)$ & & $15(75)$ & \\
Riwayat DM & $10(33.3)$ & $5(25)$ & \\
$\quad$ Ya & $20(66.7)$ & & & \\
Tidak & & & $4(20)$ & \\
Riwayat Kolesterol & & & $16(80)$ & \\
$\quad$ Ya & $7(23.3)$ & & & $5.12(4.70)$ \\
Tidak & $23(76.7)$ & $3.50(3.30)$ & & \\
NIHSS awal & & $2.04(3.32)$ & & \\
NIHSS akhir & & & & \\
\hline
\end{tabular}

Kedua, keadaan hiperglikemia akan memperparah keadaan asidosis karena adanya penimbunan asam laktat, sehingga meningkatkan pembentukan radikal bebas, mengganggu transduksi sinyal intraseluler dan aktivasi dari endonuklease. Hal ini akan menimbulkan kerusakan yang lebih luas pada jaringan otak. Ketiga, hiperglikemi akan merangsang dikeluarkannya asam amino tertentu, terutama glutamat, yang berperanan penting dalam mengaktivasi reseptor glutamat post-sinaptik, terutama reseptor NMDA (N-methyl-D-aspartate). ${ }^{10}$ Berdasarkan hasil penelitian ini dapat disimpulkan bahwa belum cukup bukti kadar GDP dapat digunakan sebagai prediktor yang baik untuk menentukan luaran klinis pasien stroke iskemik fase akut. Diperlukan indikator pemeriksaan lain yang lebih baik dalam memprediksi luaran klinis pasien stroke iskemik pada fase akut.

\section{Simpulan}

Terdapat hubungan antara kadar gula darah puasa dengan angka NIHSS masuk dengan cut-off 7 serta nilai luaran NIHSS yang lebih buruk. 


\section{Daftar Rujukan}

1. Global Health Estimates. Geneva: World Health Organization; 2012. Available from: http://www.who.int/healthinfo/global burden d is ease/en/

2. Departemen Kesehatan Republik Indonesia. Risiko Utama Penyakit Tidak Menular Disebabkan Rokok. Jakarta: Kementrian Kesehatan Republik Indonesia. 2013.

3. Owolabi MO, Akarolo-Anthony S, Akinyemi R, et al. The burden of stroke in Africa: a glance at the present and a glimpse into the future. Cardiovasc J Afr. 2015;26(2):27-38.

4. Stroke Association. Stroke Statistics (Online). http://www.stroke.org.uk/resourcesheet/stroke-statistics

5. O'Donnell MJ, Xavier D, Liu L, et al. Risk factors for ischaemic and intracerebral haemorrhagic stroke in 22 countries (the INTERSTROKE study): a case - control study. Lancet. 2010;376:112-23.

6. Nardi K, Milia P, Eusebi P, et al. Predictive value of admission blood glucose level on short-term mortality in acute cerebral ischemia. Journal of Diabetes and Its Complications. 2012;26(2):70-76

7. Woo J, Lam CW, Kay R, et al. The influence of hyperglycemia and diabetes mellitus on immediate and 3 - month morbidity and mortality after acute stroke.Arch neurol. 1990;47(11):1174-1177
8. Shah R, Vyas C, Vora J. NIHSS Score : A handy tool to predict vascular occlusion inacute ischemic stroke. NHL Journal of Medical Sciences.2014;3(2):18-22

9. Darmawan A, Tugasworo D, Gde T, \& Pemayun, D. Hiperglikemia dan Aterosklerosis Arteri Krotis Interna pada Penderita Pasca Stroke Iskemik. Media Medika,2011;45:1-7

10.Badrul M, Rasyid H, Rosita R. Relationship Between the Random Blood Glucose Levels During Admission at Emergency Room With Clinical Output in Acute Ischemic Stroke Patients. MNJ. 2015;1(2):52-60

11.Adams HP, Jr, Bendixen BH, Kappelle LJ, et al.Baseline NIH Stroke Scale score strongly predicts outcome after stroke: A report of the Trial of Org 10172 in Acute Stroke Treatment (TOAST). Neurology. 1999;24:35-41

12.Degraba TJ, Hallenbeck JM, Pettigrew KD, et al. Progression in acute stroke: value of the initial $\mathrm{NIH}$ stroke scale score on patient stratification in future trials. Stroke. 1999;30(6): 1208-1212

13.Askim T, Bernhardt J, Churilov L, Indredavil B.The Scandinavian Stroke Scale is Equally as Good as the National Institutes of Health Stroke Scale in Identifying 3-Month Outcome. J Rehabil Med.2016;46:909-912 